the Cr-poor discrete nodules. However, a straightforward transformation of coarse $\rightarrow$ deformed $\rightarrow \mathrm{Fe}-\mathrm{Ti}$ enriched deformed therzolites is not probable because some of the deformed lherzolites are more magnesian than some of the coarse ones. Hence the relationship of coarse and deformed lherzolites and $\mathrm{Cr}$-poor discrete nodules is still uncertain.

\section{REFERENCES}

Boyd, F.R., P.H. Nixon, and N.Z. Boctur, 1981: Ann. Rev. Dir. Geophys. Lab., 80, 328-336.
BovG, F.R., and P.H. Nixon, 1973: Lesotho Kimberlites, $254-268$.

Eggler, D.H., Y.E. McCallum, and C.B. Smith, 1979: The Mantle Sample, 213-226.

Hosserty, S.E., 1975: Phys. Chem. Earth, 9, 295-307.

lindslev, D.H., and S. A. Dixon, 1975: Am. J. Sci. $276,1285-1301$.

Perkins, D. III, and R.C. Newton, 1980: Contrib. Mineral. Petrol., 75, 291-300.

Robey, J., and J.J. Gurney, 1979, Kimberlite Symposium $[\mathrm{I}$, Cambridge.

s.chulze, D.J., 1981 , EOS, 62, 414.

Sclulze, D.J., and J.D. Hoover, 1982, EOS, 63.

\title{
COMPOSITIONAL AND TEXTURAL FEATURES OF PERIDOTITE NODULES FROM THE JAGERSFONTEIN KIMBERLITE PIPE, SOUTH AFRICA
}

Ben HARTE', John J. GURNEY²

'Grant Institute of Geology, University of Edinburgh. Scotland.

${ }^{2}$ Dept. of Geochemistry, University of Cape Town, South Africa.
Examination in the fleld of large $(>8.0 \mathrm{~cm})$ nodules at a variety of locations around the Jagersfontein mine area reveal that about $80 \%$ are coarse-grained peridotites with no obvious fabric or modal layering. The majority of these nodules are close to being harzburgites with only traces (1n hand specimen) of other phases, though there are trans1tions to peridotites with ca. 5\% clinopyroxene and/or garnet. Dunites, pyroxenites and ecologites form together about $5 \%$ of large nodules. The remainder (ca. $15 \%$ ) of the large nodule population is essentially formed by deformed peridotites (porphyroclastites or flaser gneisses in hand specimen), which differ modally from the coarse peridotites in commonly belng garnet-1herzolites with conspicuous ( $>5 \%$ ) clinopyroxene and garnet. Counts of small nodules $(<8.0 \mathrm{~cm})$ show a higher proportion (ca. 35\%) of deformed peridotites, but maintain the bias to harzburgitic assemblages in coarse peridotites and to garnet-lhezolites amongst deformed peridotites.

\section{Coarse Peridotites}

Microscopic and chemical-analytical investigations show that many of the coarse peridotites have detailed petrological affinities to one another. Olivine and orthopyroxene are always the dominant modal phases, but minor amounts of: clinopyroxene, garnet, amphibole, and chromian spinel also commonly occur. Often only two of these additional minerals occur as primary phases, but all combinations have been found including the six-phase assemblage: olivine + orthopyroxene + clinopyroxene + garnet + amphibole + Crspinel. A feature of many coarse nodules is the presence in the orthopyroxene of exsolution lamellae of spinel, which may be accompanied by fine birefringent exsolution lamellae (probably of clinopyroxene) and also garnet lamellae. Exsolution lamellae range up to about $0.1 \mathrm{~mm}$ across. Sometimes garnet, and to a lesser extent spinel, form small grains orientated along grain boundaries and arranged in partial "necklets' reminescent of granular exsolution. Another feature is the occurrence of occasional vermicular intergrowths of clinopyroxene and spinel in some garnet-free rocks.

The amphibole is an edentic hornblende (Leake 1978) and 1 ts relatively widespread though not abundant occurrence at Jagersfontein (first reported by Johnston 1973) is unusual by comparison with peridotite nodules from other kimberlites. In general, coarse-nodule mineral compositions are tightly restricted. Some features are shown in $\mathrm{Ca}: \mathrm{Mg}: \mathrm{Fe}$ projection in figure 1 . The $\mathrm{Al} / \mathrm{Al}+\mathrm{Cr}$ ratios are: $62-72 \%$ in clinopyroxene, $86-90 \%$ in amphibole, $90-94 \%$ in garnet, and $28-54 \%$ in spinel. $\mathrm{Mg} /(\mathrm{Mg}+\mathrm{Fe})$ ratios in orthopyroxene are 95$91 \%$, and $68-56 \%$ in spinel. $\mathrm{Al}_{2} \mathrm{O}_{3} \mathrm{wt} \%$ in orthopyroxene varies up to $3.3 \%$ in garnet-free assemblages, but is close to 0.65 in garnet-bearing rocks. In two thin sections exsolution lamellae of spinel and garnet in orthopyroxene gave virtually identical compositions to those of independent grains. In the clinopyroxene- spinel symplectites mineral compositions are also close to those of independent grains, as found in similar intergrowths by Dawson and Smith (1975). One unusual garnet harzburgite shows zoning of olivine and orthopyroxene compositions with variation of 93 to $89.5 \% \mathrm{Mg} /(\mathrm{Mg}+\mathrm{Fe})$ in the olivine, and corresponding variation in the orthopyroxene together with minor increases in $\mathrm{Ca}$ and $\mathrm{Al}$. The garnet compositions in this rock are constant, and 1 t is suspected that the rock underwent contamination (or metasomatism) in contact with melt.

The common coarse nodules which appear to form part of a coherent group were probably sampled from a restricted region of the upper mantle. They appear to have originated at high temperatures and cooled very slowly (possibly whilst depressurisation occurred) to allow the exsolution to proceed and the intergrowth compositions to maintain approximate equilibrium with all phases. $\mathrm{Ca} /(\mathrm{Ca}+\mathrm{Mg})$ ratios in clinopyroxenes are uniformly close to $50 \%$ and temperatures indicated by $\mathrm{Fe} / \mathrm{Mg}$ distribution in coexisting garnet and clinopyroxene (Mori and Green 1978) are in the range 800$875^{\circ} \mathrm{C}$. The mineral equilibria had probably become frozen prior to sampling by the kimberlite (Harte and Freer, this volume).

Deformed Peridotites

These nodules fall predominantly into the porphyroclastic and mosaic-porphyroclastic groups of Harte (1977). Some of the mosaic-porphyclastites also show laminar and fluidal textures. Also included in this group are occasional nodules which are transitional between coarse and porphyroclastic textural types, and some which show fine to medium grained granuloblastic textures (perhaps indicating complete recrystallisation and grain growth after deformation). Garnet and clinopyroxene are common phases in addition to olivine and orthopyroxene, but amphibole and spinel have not been found as primary independent phases. However, fine exsolution lamellae of spinel appear to be present within orthopyroxene porphyroclasts in a few nodules.

Mineral compositions are more variable in this group than in the coarse nodules. In addition to the features shown in figure 1 it may be noted that $\mathrm{Al} /$ $(\mathrm{Al}+\mathrm{Cr})$ varies from 45 to $90 \%$ in clinopyroxenes, and from 65 to $97 \%$ in garnets. The range of $\mathrm{Al}_{2} \mathrm{O}_{3}$ in orthopyroxene is however quite restricted between 0.45 and 1.11 wt \%: whilst $\mathrm{Mg} /(\mathrm{Mg}+\mathrm{Fe})$ in this phase varies from 93 to $88 \%$. In most rocks the mineral compositions are homogeneous, but in two cases the olivine and orthopyroxene neoblasts show marginally higher Fe/ $\mathrm{Mg}$ than the porphyroclasts. Temperature estimates, using $\mathrm{Fe}-\mathrm{Mg}$ distribution between garnet and clinopyroxene (Mori and Green 1978), show a range of 1140 to $1380^{\circ} \mathrm{C}$ for the deformed nodules. But some nodules show a lack of correspondence between different geothermometers, which may indicate some disequilibrium. The wide spread of temperature estimates is unusual 


\section{JAGERSFONTEIN PERIDOTITES}

\section{(Harte and Gurney)}

FIG. I

$\triangle$ COARSE with amphibole - COARSE without amphibole -PORPHYROCLASTIC

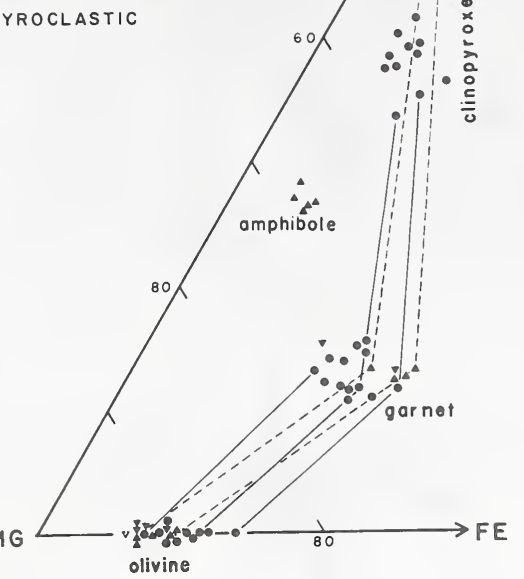

by comparison with the limited temperature range at a single kimberlite pipe of many deformed peridotites (group V of Gurney and Harte 1980, Table 1).
As partly shown in figure 1 the $\mathrm{Mg} /(\mathrm{Mg}+\mathrm{Fe})$ mineral compositions of the coarse and deformed peridotites overlap but with the olivines and pyroxenes tending to have higher $\mathrm{Mg} /(\mathrm{Mg}+\mathrm{Fe})$ in coarse nodules. Similar relations are seen in bulk rock analyses of the two groups. Another distinction in bulk rock chemistry between the coarse and deformed groups is a tendency for the deformed peridotites to show higher $\mathrm{TiO}_{2}$ contents. These features correspond to those seen in nodules from other kimberlite pipes (e.g. Gurney and Harte 1980). Derivation of the deformed rocks from originally coarse rocks is indicated texfurally, and the rare presence of spinel exsolution lamellae in some orthopyroxene porphyroclasts is particularly interesting in that it suggests derivation from relatively low-temperature coarse rocks; perhaps in a process of the type suggested by Gurney and Harte (1980). However, the coarse protoliths for the deformed nodules do not appear to be the rocks represented by the common coarse nodules. This is indicated by the modal differences of the two groups of nodules, since the abundance of garnet and clinopyroxene porphyroclasts in the deformed'rocks makes it unlikely that the modal differences are solely a product of metasomatism.

Dawson, J.B., and J.V. Smith, 1975: Phys. Chem. Earth 9, 339-350.

Gurney, J.J., and B. Harte, 1980: Phil. Trans. R. Soc. Lond A297, 273-293.

Harte, B., 1977: J. Geol. 85, 279-288.

Johnston, J., 1973: Extended Abstrs, lst Int. Kimb. Conf., 181-183.

Mori, T., and D.E. Green, 1978: J. Geol. 86, 83-97.

ACKNOWLEDGEMENT: We wish to thank De Beers Consolidated Mines Ltd. and J.B. Hawthorne for financial support and assistance with field work arrangements.

\section{CORUNDUM-BEARING GARNET PYROXENITES AT BENI-BOUSERA (MOROCCO) : AN EXCEPTIONNALLY AL-RICH CLINOPYROXENE FROM "GROSPYDITES" ASSOCIATED WITH ULTRAMAFIC ROCKS.}

J. KORNPROBST, M. PIBOULE, M. BOUDEULLE and L. ROUX

Departement de Geologie, LA 10 et IOPG - 5, rue Kessler, 63000 Clermont-Ferrand.

First described by Milliard (1950) the ultramafic Beni-Bousera body (northern Morocco) exhibits spinel-1herzolites and harzburgites associated with spinel and/or garnet pyroxenite layers. The main assemblages belong to the "ariegite subfacies" (O'Hara, 1967) and have been ultimately equilibrated under high pressure granulite facies conditions (10-12 Kbar ; $\left.900^{\circ} \mathrm{C}\right)$ together with the surrounding paraderived country rocks, before their tectonic uplift to their present geological environment (Kornprobst, 1969). The various pyroxenite layers have been interpreted as the crystallization products of a melt extracted from the surrounding peridotites during an adiabatic diapiric rise of a fragment of the upper mantle. This interpretation is supported by experimental (Kornprobst, 1970) and geochemical (Javoy, 1970 ; Loubet and Allegre, 1979) data.

The primary crystals precipitated from the melt most generally recrystallized in the solid state but could be recognized and their compositions approximately recalculated ; they appear to be mainly $\mathrm{Mg}-\mathrm{rich}$ clinopyroxenes involving a large range of $\mathrm{Mg}$-Tschermak solid solution and up to $10 \% \mathrm{~A} 1203$ contents. A new primary assemblage has been recent ly discovered, characterized by the presence of corundum associated with Ca-rich garnet and Ca-Tschermak- and jadeite-rich clinopyroxene (A1203 up to $2 \% \%$ ).

I/ THE PRIMARY ASSOCIATION : A CORUNDUM BEARING "GROSPYNITE"

The corundum-bearing rocks have not been found in place and the structural relationships with the peridotites are unknown. They are layered and exhibit sharp compositional variations across a $f e w \mathrm{~cm}$. The

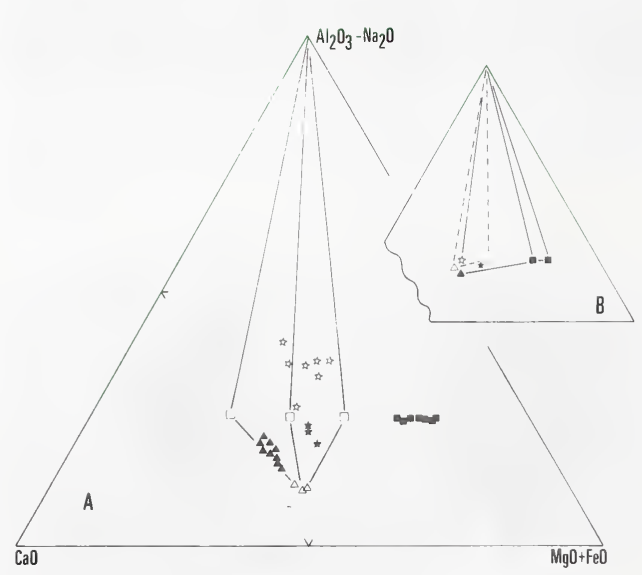

Fig. 1: The "grospydites" from the Beni Bousera body: solid symbols; stars= bulk rock compositions; squares = garnets; triangles = clinopyroxenes.

$1 A-$ Molecules \% : comparison with the grospydites from yakutia (sobolev et al., 1965 ; 1968); same symbols as above, open.

1B- Weight \%: comparison with Boyd's experimental results (1970); same symbols as above, open. 